\title{
Recruitment Selection Process with Refernce to Trimastir Solution Pvt Ltd
}

\author{
M. Suresh, R. Ravimohan, S. Krupa
}

\begin{abstract}
Enrollment is the way toward scanning for planned representatives and animating them to apply for employments in the association.

Choice could be defined as the operation by which the organization watches over among the applicants, those people they think would best fulfill the precondition of the exercise, thinking about the present natural situation. In the current quickly changing business condition, associations have to to retort rapidly to prerequisites for individuals.

It is therefore vital to set up a well-characterized enlistment policy that can be properly performed in order to get the greatest suits for vacant roles. Choosing an inappropriate competitor or rejecting the right up-and-comer could result in the partnership being exorbitant mistakes.
\end{abstract}

\section{INTRODUCTION}

Human Resources Management refers to any association's effective manner of dealing with the problems. It is concerned that professors will be enlisted, prepared and developed. Human asset is the most significant resource of an association. It guarantees ample supply, legitimate amount and just as viable use of HR [1,2].

A bit of Human Resources Management is consigned to personnel who play out a part of the staffing limit. The staffing method is a movement of events, which result in a relentless managing progressive position at, all levels from the top organization to the usable's level. This technique joins work orchestrating, endorsement for organizing; making wellsprings of applicant evaluation of employments work (decision) offers (position) enrollment and bearing, moves, downsizes, headways and separations $[3,4]$.

Enrollment is concerned about the manner to work for different jobs in skilled and sectors. This includes the distinct evidence of the job advertisement's current wellsprings, the enhancement of fresh sources, and the need to pull in enormous numbers of prospective apps with the objective of making excellent decisions possible.

Decision methodology is stressed over the progression of assurance approaches and technique and the appraisal of potential specialists with respect to work subtleties. This method consolidates the improvement of use spaces, real and reliable tests, chat with methodologies laborer reversal systems, appraisals and judgments of personnel in regards to

Revised Manuscript Received on July 22, 2019.

M. Suresh*, Department of Management Studies, Bharath Institute of Higher Education and Research, Chennai, Tamilnadu, India

R. Ravimohan Department of Management Studies, Bharath Institute of Higher Education and Research, Chennai, Tamilnadu, India

S. Krupa, Department of Management Studies, Bharath Institute of Higher Education and Research, Chennai, Tamilnadu, India occupations subtleties the creation up of unmistakable recommendations [5-8].

\section{OBJECTIVES OF THE STUDY}

\section{A. Essential}

To comprehend the present Recruitment being pursued at "TRIMASTIR SOLUTIONS PVT. LTD" led this examination and to know how successfully it is being actualized in the association [9].

\section{B. Optional}

- To study the various strategies for enlistment and determination relying upon the prerequisites of the association.

- To study the degree of occupation fulfillment in the association.

- To study the progressions of enrollment approach as of late in the association.

- To know how the organization satisfies its labor necessities [10].

\section{REVIEW OF LITERATURE}

In any case, an extensive writing stream likewise proposes that there exist disappointment in workers with respect to execution examination framework [11] Earlier findings by Smither and London (2009) have explained in a comparable vein that 80-90 percent of managers reflect that exhibition assessment was not strong in enhancing the execution of representatives and organizations [12].

Composing has recognized a couple of markers that impact the aftereffects of execution assessment structure. In such way, one essential factor is the assessment source. This factor recommends that specialist execution can be evaluated through various sources, for instance, managers, directors, self, peers and even customers [13,14]. Another noteworthy typical for execution assessment is the explanation behind which execution has been surveyed or surveyed [15], and normally, execution assessment structures are utilized for various purposes stretching out from developmental and administrative purposes. Info riches is in like manner a fruitful marker that may impact the aftereffects of execution assessment. Analysis indulgence elucidates the specific assessment condition by which nonstop, express and helpful information is given by agents to directors as for work [16]. Seen accuracy of execution assessment has been seen as a critical point of view to survey the satisfaction and motivation in

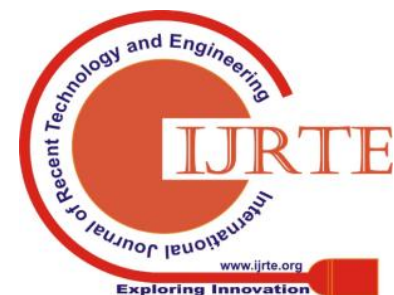


laborers in association with execution assessment [17-20].

In such way, prior assessments prescribe that if delegate see that assessment results are exact, they will undoubtedly see these results and follow up on them [21,22].

Then again, worker impression of reasonableness likewise measures viability of execution evaluation results $[23,24]$. In this regard, past examinations have recommended that equity or decency of execution examination can be assessed into three measurements. These are distributive, interactional decency and procedural [25]. In such manner, distributive decency speaks to the degree to which results of evaluation are conveyed decently [26]. In the examination setting, the distributive setting relates with the evaluations of execution evaluation picked up by workers. Then again, procedural reasonableness goes for the degree to which methodology conveyed by association for examination are reasonable in determining results of evaluation [27]. In opposition to this, the idea of interactional reasonableness speaks to the degree to which workers get treatment of companions and bosses during the way toward assessing execution [28].

Prior composing has recommended that show assessment is a convincing structure for achieving different goals. In such way, Selvarajan and Cloninger (2009) have revealed that effective execution assessment structure achieves improving execution of agents and moving them. In such way, it will in general be perceived who are the delicate performers and who strong performers inside affiliations are [29]. In a comparative line of thought, prior assessments have recognized five critical consequences of convincing execution assessment [30]. These are: 1) using results of execution assessment to improve agent execution, 2) overhauling motivation, 3) lessening specialist turnover, 4) accomplice prizes and delegate execution and 5) setting up an incentive among laborers [31,32].

\section{SIGNIFICANCE OF THE STUDY}

It is the strategy of division between competitors to perceive (and utilize) those with a progressively vital likelihood of accomplishment in a work. Decision of work power to man the affiliation is a basic, marvelous and continuing with limit. The limit of a relationship to accomplish its destinations effectively and to make in a dynamic circumstance, all things considered, depends on the suitability of its assurance program. In the occasion that right staff is picked the remainder of the components of work power the administrators winds up more straightforward. In an opposite condition where the right individual isn't picked, the remainder of the components of workforce the board, laborer relations won't urge [33].

\section{OBJECTIVES}

I had begin my Management Training with Trimastir Solutions Pvt Ltd as HR official or you can say as a Talent obtaining and I have the point Recruitment and Selection
Process in Trimastir as a Project Topic. I have work with Trimastir for the 60 days which conveys two months. Inside this period I have the more extensive information in HR field just as Marketing. Since my work was identified with both field where I have truly actualize my HR and Marketing information in a workplace.

Here in Trimastir I fill in as a person just as in a gathering likewise and become familiar with the bunches of things. Here I have the more extensive information of enrollment procedure and how as a HR and Marketing individual act in the workplace.

\section{RESEARCH DESIGN}

The examination is to quantify adequacy of the preparation program through execution evaluation framework given by the workers.

Unmistakable research is also referred to as factual studies. This type of research's basic goal is to describe the data and characteristics about what is deemed. The idea behind such studies is to consider frequencies, midpoints and other measurable computations. Although this test is extremely accurate, it does not collect the causes behind circumstance.

\section{If fresh positions were evaluated in their company}

\begin{tabular}{|l|l|l|}
\hline Options & No.of. Respondents & Percentage \\
\hline Yes & 30 & 50 \\
\hline No & 6 & 10 \\
Don't know & 24 & 40 \\
\hline Total & 60 & 100 \\
\hline
\end{tabular}

Table 8

The requirement of manpower is identified well in advance considering

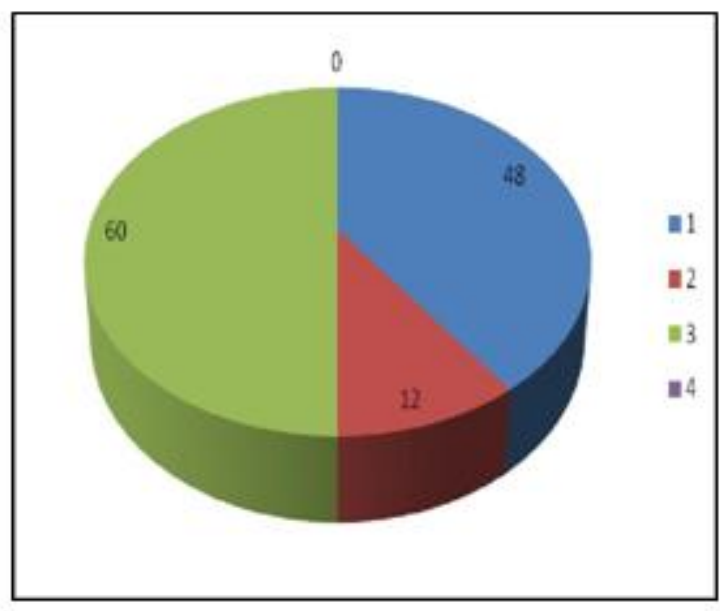

INTERPRETATION: Of the 60 assenters whose opinion was asked if the manpower 
requirement was identified well in advance in each department, 80 percent responded in the affirmative and 20 percent said no.

Of the 60 employees whose opinion on the planning of the workforce requirement was requested, all staff agreed that the planning of the workforce requirement was carried out in the light of the organization's business plans.

\section{RESULTS AND DISCUSSION}

1) The investigation demonstrates that $76 \%$ of the workers who have put in difficult year of administration have enrolled by means of open challenge. This demonstrates the straightforwardness of the enrolling arrangements of the organization $92 \%$ of the representatives have been working in the association for an extensive stretch which means the professional stability and fulfillment presented by the organization to its workers.

2) Our investigation demonstrates that $44 \%$ of the representatives have joined this association going for vocation development and more advantages which the organization offers. Subsequently the measurements demonstrates that the organization has an uplifting viewpoint towards the profession development of its representatives notwithstanding the other existing advantages.

3) The organization's way to deal with its enrollment strategy demonstrates that the ideal individual is fundamental for the correct activity, as almost $88 \%$ of the workers felt that they were extended employment opportunities as per their capability and experience. In this way setting a connection among capability and employment advertised.

4) The examination demonstrates that $72 \%$ of the representatives were of the conclusion that the enrollment approach of the organization is decentralized with every office selecting its own workers according to their necessity from an opportunity to time.

\section{CONCLUSION}

Coming up next are the resolutions:-

- The wellspring of enlistment in the association is completely situated in both the elements for example inward and outer.

- The enlistment of the imminent possibility for a specific post is situated in understanding, age, capability and rate in the scholastic year.

- The choice procedure is completely founded on abilities, correspondence and specialized characteristics.

\section{REFERENCES}

1. BharthVajan R., Ramachandran S.,Psychographic dimensions of training,2016,International Journal of Pharmacy and Technology,V-8,I-4,P-23727-23729
2. Balakrishnan P., Bharthvajan R.,A study on human resource planning in hospitals in Chennai City,2014,International Journal of Applied Engineering Research,V-9,I-22,P-7503-7507

3. Priyadarsini P., Bharthvajan R.,Role of emotional intelligence training programme in reducing the stress of the nurses,2014,International Journal of Applied Engineering Research,V-9,I-22,P-7411-7421

4. Kerinab Beenu G., Bharthvajan R.,Empirical analysis on the cosmetic buying behavior of young women in South India,2014,International Journal of Applied Engineering Research,V-9,I-22,P-7361-7366

5. Balakrishnan P., Bharthvajan R.,Whistling in the wind,2014,International Journal of Applied Engineering Research,V-9,I-22,P-7586-7593

6. Krishnan B., Peter M.,Health hazards of Indian Bpo employee-an alarming issue,2014,International Journal of Applied Engineering Research,V-9,I-22,P-7336-7341

7. Kerinab Beenu G.H., Peter M.,Role of insurance in economic development,2014,International Journal of Applied Engineering Research,V-9,I-22,P-7532-7539

8. Balakrishnan P., Peter M., Priyadarsini P.,Efficiency of safety measures for wellbeing of employees in manufacturing industry,2014,Internationa Journal of Applied Engineering Research,V-9,I-22,P-7376-7382

9. Anbarasi M., Praveen Kumar S.,Online sales promotions of herbal products and its effectiveness towards tanisha.com,2019,Indian Journal of Public Health Research and Development,V-10,I-1,P-195-200

10. Anbarasi M., Praveen Kumar S.,Various online marketing and promotions strategies to improve the validation towards the organic products in the pharmaceutical sectors,2019,Indian Journal of Public Health Research and Development,V-10,I-1,P-263-269

11. Loganathan R., Praveen Kumar S.,Grievance handling a key factor for solving issues of employees in an organization,2014,International Journal of Applied Engineering Research,V-9,I-22,P-7483-7491

12. Loganathan R., Praveen Kumar S.,Study on preference of private label brands in super and Hypermarkets,2014,International Journal of Applied Engineering Research,V-9,I-22,P-7327-7335

13. Smitha M., Praveen Kumar S.,Understanding stress and its managementamong the nurses in Chennai city,2014,International Journal of Applied Engineering Research,V-9,I-22,P-7560-7565

14. Kerinab Beenu G.H., Praveen Kumar S.,A study on the investment behavior of Chennai investors in mutual fund schemes,2014,International Journal of Applied Engineering Research,V-9,I-22,P-7520-7525

15. Loganathan R., Praveen Kumar S.,Retention strategies key for organizational productivity,2014,International Journal of Applied Engineering Research,V-9,I-22,P-7443-7447

16. Pavithra J., Ganesan M., Brindha G.,State wise analysis of microfinance sector in India,2016,International Journal of Pharmacy and Technology,V-8,I-4,P-23417-23432

17. Pavithra J., Ganesan M.,A comparative study on microfinance in India and abroad,2016,International Journal of Applied Business and Economic Research,V-14,I-8,P-5471-5476

18. Pavithra J., Ganesan M.,A study on awareness and impact of micro-financial schemes,2016,International Journal of Applied Business and Economic Research,V-14,I-8,P-5449-5460

19. Senthilmurugan P., Pavithra J.,Consumer preference towards organised retailing with reference to Big Bazaar,2014,International Journal of Applied Engineering Research,V-9,I-22,P-7469-7475

20. Senthilmurugan P., Pavithra J.,Implication of social media marketing in growing healthcare industry,2014,International Journal of Applied Engineering Research,V-9,I-22,P-7448-7456

21. Loganathan R., Pavithra J.,Consumer perception towards private label brand over other brands in super markets and hypermarkets,2014,International Journal of Applied Engineering Research,V-9,I-22,P-7355-7360

22. Kerinab Beenu G., Pavithra J.,Tradeâ€"off between liquidity and profitability in logistics industry,2014,International Journal of Applied Engineering Research,V-9,I-22,P-7398-7401

23. Kerinab Beenu G., Pavithra J.,A study on the prospective consumerâ€ $\mathrm{TM}_{\mathrm{S}}$ perception towards utility cars in Chennai city,2014,International Journal of Applied Engineering Research,V-9,I-22,P-7526-7531

24. Pavithra J., Dilli Babu P., Ambuli T.V.,A study on budgetary control at Maruti Service Masters, Chennai,2014,International Journal of Applied Business and Economic Research,V-12,I-2,P-151-161

25. Pavithra J., Dilli Babu P., Ambuli T.V.,A study on customer satisfaction of retro Garments Pvt Ltd, Chennai,2014,International Journal of Applied Business and Economic Research,V-12,I-2,P-381-391

26. Kerinab Beenu G.H., Pavithra J., Senthilmurugan P.,A study on the influence of promotional activities for TATA ARIA among consumers in Chennai,2014,International Journal of Applied Engineering Research,V-9,I-22,P-7572-7578

27. Vijayaragavan S.P.,An investigative expert that's general FBG sensors,International Journal of 
28. Vijayaragavan S.P.,Equalization routing protocol for Wi-Fi sensor strategy,International Journal of Mechanical Engineering and Technology,V-8,I-8,PP-1662-1666,Y-2017

29. Karthik B., Kiran Kumar T.V.U., Vijayaragavan P., Bharath Kumaran E.,Design of a digital PLL using $0.35 \hat{\mathrm{I}}^{1 / 4} \mathrm{~m}$ CMOS technology,Middle East Journal of Scientific Research,V-18,I-12,PP-1803-1806,Y-2013

30. Kanniga E., Selvaramarathnam K., Sundararajan M.,Kandigital bike operating system,Middle - East Journal of Scientific Research, V

31. Jasmin M., Vigneshwaran T., Beulah Hemalatha S.,Design of power aware on chip embedded memory based FSM encoding in FPGA,International Journal of Applied Engineering Research,V-10,I-2,PP-4487-4496,Y-2015

32. Jasmin M.,Optimization techniques for low power VLSI circuits,Middle East Journal of Scientific Research,V-20,I-9,PP-1082-1087,Y-2014

33. Jasmin M., Vigneswaran T.,Fuzzy controller for error control of on - Chip communication,2017 International Conference on Algorithms, Methodology, Models and Applications in Emerging Technologies, ICAMMAET 2017,V-2017-January,I-,PP-1-5,Y-2017

\section{AUTHORS PROFILE}

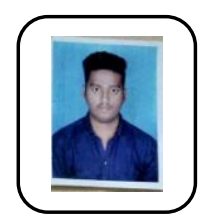

M. Suresh, Student, Department of Management Studies, Bharath Institute of Higher Education and Research, Chennai, India

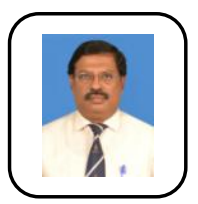

R. Ravimohan, Associate Professor, Department of Management Studies, Bharath Institute of Higher Education and Research, Chennai, India

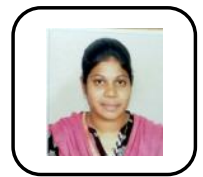

S. Krupa, Student, Department of Management Studies, Bharath Institute of Higher Education and Research, Chennai, India 